\title{
Liquidity Premium and Transaction Cost
}

\author{
Junxian Yang, Xindong Zhang \\ School of Economics and Management, Shanxi University, Taiyuan, China \\ Email: yangjxyjx@sxu.edu.cn
}

How to cite this paper: Yang, J. X., \& Zhang, X. D. (2021). Liquidity Premium and Transaction Cost. Theoretical Economics Letters, 11, 194-208.

https://doi.org/10.4236/tel.2021.112014

Received: March 2, 2021

Accepted: March 28, 2021

Published: March 31, 2021

Copyright $\odot 2021$ by author(s) and Scientific Research Publishing Inc. This work is licensed under the Creative Commons Attribution International License (CC BY 4.0).

http://creativecommons.org/licenses/by/4.0/

\begin{abstract}
Low infrequent trading implies low liquidity. Liquidity and transaction cost are two sides of the coin. Whether transaction cost is the determinant of stock liquidity premium? This paper selects common stocks of NYSE/Amex/Arca/ Nasdaq from 1926 to 2011 as research samples, makes a comprehensive analysis through Fama-French three factor model and Fama-French five factor model, LCAPM model and Pástor Stambaugh model. The results show that the ability of $B A 12, L O T 12, C S 12$, and $C^{\text {ribbs }}$ is limited, which means that transaction cost is not the determinant of liquidity premium, and the influence of transaction cost on the expected return of stock is indirect and secondary. The research provides a strong empirical experience for the asset pricing power of transaction cost is the second order. Thus, from the perspective of pricing meaning, transaction cost is not the decisive factor of price.
\end{abstract}

\section{Keywords}

Transaction Cost, Liquidity Premium, Asset Pricing, LDV Model

\section{Introduction}

Transaction cost is composed of direct transaction cost and implicit transaction cost (Demsetz, 1968), which is the comprehensive embodiment of market quality and an important factor of the core competitiveness of stock exchange. Liquidity and transaction cost are actually "the positive and negative sides of the coin". Lower transaction cost means higher liquidity. Lower transaction cost means that the stock price will not be greatly distorted due to incomplete information and sudden changes in supply and demand, which makes the market more stable. The lower transaction cost enables investors to quickly change their investment portfolio according to market information, accelerate the reaction of stock price to innovation of information, and make the market more efficient and transparent. In 1986, the Department of labor of the United States issued guideline 86-1, which requires the financial market to focus on transaction cost. 
Since then, the securities market has begun to pay attention to transaction cost. With the improvement of corporate governance, market transparency and pricing efficiency, there is less and less room to earn excess profits. Therefore, transaction cost analysis, transaction cost asset pricing power research is very important.

Transaction cost measures the width of liquidity. The research of liquidity starts from bid ask spread (Amihud and Mendelson, 1986). Stocks with lower liquidity will have higher expected return, which marks the establishment of liquidity premium theory. A lot of literatures have found that there is a high-low portfolio return gap formed by some liquidity indicators. For example, Brennan et al. (1996, 1998, 2012), Amihud (2002), Hasbrouck (2003), Pastor and Stambaugh (2003), Liu (2006), Goyenko et al. (2009). It's not surprising that portfolio return difference exists. On the meaning of asset pricing of transaction cost, Constantinides (1986) found that although transaction cost affects asset demand, the impact on asset return is the second order, that is, when investors face large transaction cost, they can adjust it by reducing transaction frequency and volume. Then, Vayanos $(1998,1999)$ thinks that the transaction cost mainly affects the holding period and trading volume, and the impact on the expected return is the second order. But it's worth noting that the large magnitude of portfolio return difference in the United States, Anthony and Tan (2011) found that the magnitude of liquidity premium and transaction cost spread is the first order, and transaction cost has asset pricing power. It can be seen that theoretically, whether the asset pricing power of transaction cost is first-order or second-order is still in dispute. Is transaction cost the determinant of asset return and can it be ignored in asset pricing? Does transaction cost directly or indirectly affect stock expected return? This paper attempts to find the answer from the comprehensive empirical research and fill in the empirical evidence of this problem. Due to the diversity and difference of transaction cost indicators, this paper selects four classic transaction cost estimates: Amihud \& Mendelson (1986), Lesmond et al. (1999), Hasbrouck (2009), Corwin and Schultz (2012). This paper takes the common stock of American stock market from June 1927 to December 2011 as the research sample to comprehensively explore the ability of transaction cost to predict stock returns.

The rest of this paper is organized as follows. Section 2, the measurement of transaction cost index and its correlation analysis. Section 3, the liquidity premium test based on Fama-French asset pricing model. Section 4 is the cross-sectional regression analysis at the stock level. Section 5, the portfolio performance test adjusted by liquidity risk. Section 6 is the robustness test. Section 7 is the conclusion.

\section{Data and Transaction Cost Measures}

\subsection{Data}

Our sample includes all NYSE/Amex/Arca/Nasdaq ordinary common stocks over 
January 1926 to December 2011. Because trading volumes for Nasdaq stocks are inflated relative to NYSE/Amex/Arca stocks due to interdealer trades, our main tests are based on NYSE/Amex/Arca stocks. To check the robustness, we also test them using NYSE/Amex/Arca/Nasdaq stocks. Daily trading volume and number of shares outstanding, monthly return and market value (MV) ${ }^{1}$, and annual accounting data for calculating the book-to-market (B/M) come from the CRSP/ COMPUSTAT merged (CCM) database. The construction of B/M follows Davis et al. (2000) and we assume that book equity data are publically available five months after the fiscal year end date ${ }^{2}$. We download the monthly values of the three Fama-French factors and the five Fama-French factors, and the traded liquidity factor of Pastor and Stambaugh (2003) from WRDS.

\subsection{Transaction Cost Measures}

The advantages and disadvantages of transaction cost estimation are related to the estimation methods. In this paper, four classical transaction cost estimation methods are selected to measure the transaction cost indicators.

- BA12: Amihud and Mendelson (1986) daily quoted bid-ask spread averaged over the prior 12 months. For NYSE/Amex/Arca stocks, the CRSP daily bid and ask prices are closing bid and closing ask prices, but for Nasdaq stocks we use the inside quotation as the bid and ask prices.

- LOT12: Lesmond et al. (1999) first constructed the LDV model (limited dependent variable) based on the hypothesis of information trading absence on non-zero return day and information trading absence on zero return day, and estimated the effective spread of parameter sum by maximum likelihood estimation. The calculation of this nonlinear maximum likelihood estimation is complex. About calculation, we make two improvements. First, the improvement of the estimation window. Lesmond et al. (1999) had a fixed estimation window of 252 days. Considering the particularity of double weekdays and February days, holidays and other factors, we improve the estimation window to 12 months. We requires that the number of non-zero return days in 12 months should be at least 16 days. Secondly, we optimize the execution algorithm. The process of sac NLP in sas9.3 is used to implement the Newton Raphson optimization algorithm. For the core program of nonlinear maximum likelihood estimation, refer to Gallop (2007).

- CS12: Corwin and Schultz (2012) work out their bid-ask spread estimate each month based on daily high and low prices in the month. In this paper, our test uses the average Corwin-Schultz spread over the prior 12 months and denote this average as CS12.

- C $C^{\text {ibbs: }}$ Hasbrouck (2009) improved Roll's (1984) effective transaction cost estimation. Its main technique is to generate Gibbs sampler, and use Bayesian

${ }^{1}$ Monthly returns are adjusted for delisting following Shumway (1997).

${ }^{2}$ Book equity data before 1951 are hand-collected by Davis et al. (2000) and downloaded from French's website. 
method to get the point estimation of parameter $C$.

We analyze the correlation between the four transaction cost indicators. Table 1 shows Pearson correlations between liquidity measures. The average and maximum values of the correlation coefficients of the three sample periods are listed in Table 1 . Over the full sample period 1927 to $2010, B A 12$ is highly correlated with LOT12 at 0.988 , is highly correlated with $\mathrm{CS} 12$ at 0.935 , is highly correlated with $C^{g i b b s}$ at 0.972 , the average correlation coefficients were $0.808,0.791,0.852$. The correlation between CS12 and LOT12 is 0.770 . low at 0.065 . The correlation between CS12 and $C^{\text {ibbs }}$ is 0.821 . The correlation between LOT12 and $C^{\text {gibbs }}$ is 0.872 . These indicate that the four transaction cost indicators do capture information from the trading cost. On the other hand, there are small differences in their ability to describe the trading cost. We observe the similar magnitudes and patterns over the two subperiods 1927-1963 and 1964-2011.

Because of the strong linear correlation between the four transaction cost indicators. Therefore, the principal component analysis of $B A 12, L O T, C S 12$ and $\mathrm{C}^{\text {gibbs }}$ was carried out, extract the first principal component, and calculate the factor score. This factor named as the comprehensive transaction cost factor, CO-cost.

Table 1. Pearson correlations. This table reports the Pearson correlations between the transaction cost measures adopted in this paper. (a) 192712 - 196312; (b) 196412 - 200912; (c) $192712-200912$.

(a)

\begin{tabular}{cccccccccc}
\hline & & \multicolumn{4}{c}{ MEAN } & \multicolumn{5}{c}{ Maximum } \\
\cline { 3 - 9 } & & YAE12 & CS12 & c $^{\text {Gibbs }}$ & LOT12 & BA12 & CS12 & c $^{\text {Gibbs }}$ & LOT12 \\
\hline BA12 & 37 & 1 & 0.823 & 0.857 & 0.796 & 1 & 0.928 & 0.972 & 0.940 \\
CS12 & 37 & & 1 & 0.807 & 0.760 & & 1 & 0.945 & 0.920 \\
$c^{\text {Gibbs }}$ & 37 & & & 1 & 0.887 & & & 1 & 0.975 \\
\hline
\end{tabular}

(b)

\begin{tabular}{cccccccccc}
\hline & & \multicolumn{4}{c}{ MEAN } & \multicolumn{5}{c}{ Maximum } \\
\cline { 3 - 9 } & YAERS & BA12 & CS12 & c $^{\text {Gibbs }}$ & LOT12 & BA12 & CS12 & c $^{\text {Gibbs }}$ & LOT12 \\
\hline BA12 & 47 & 1 & 0.765 & 0.847 & 0.817 & 1 & 0.935 & 0.959 & 0.988 \\
CS12 & 47 & & 1 & 0.832 & 0.778 & & 1 & 0.945 & 0.944 \\
$c^{\text {Gibbs }}$ & 46 & & & 1 & 0.860 & & & 1 & 0.982 \\
\hline
\end{tabular}

(c)

\begin{tabular}{cccccccccc}
\hline & & \multicolumn{4}{c}{ MEAN } & \multicolumn{5}{c}{ Maximum } \\
\cline { 3 - 10 } & YAERS & BA12 & CS12 & $c^{\text {Gibs }}$ & LOT12 & BA12 & CS12 & $c^{\text {Gibbs }}$ & LOT12 \\
\hline BA12 & 84 & 1 & 0.791 & 0.852 & 0.808 & 1 & 0.935 & 0.972 & 0.988 \\
CS12 & 84 & & 1 & 0.821 & 0.770 & & 1 & 0.945 & 0.944 \\
$c^{\text {Gibbs }}$ & 84 & & & 1 & 0.872 & & & 1 & 0.982 \\
\hline
\end{tabular}




\section{The Liquidity Premium}

We begin our empirical tests with portfolios sorted respectively by the five transaction cost measures: BA12, LOT12, CS12, $\mathrm{C}^{\text {gibbs }}$ and CO-cost. For BA12, LOT12 and $C S 12$, we form portfolios at the end of December each year and hold them for the subsequent 12 months from July to next June. For $\mathrm{C}^{\text {gibbs }}$ and $\mathrm{CO}$-cost, we form portfolios at the end of June each year and hold them for the subsequent 12 months from January to December of next year. In the pre-1963 period, the sample includes NYSE stocks only and we classify them into quintile portfolios (in the robustness check section, we also use decile portfolios over the pre-1963 period). In the post-1963 period, we form decile portfolios with NYSE breakpoints. We measure portfolio performance/return on the monthly basis and calculate the holding-period monthly portfolio returns based on the decomposed buy-and-hold method of Liu and Strong (2008)3. We mainly rely on the FF3FM as a benchmark to work out the risk-adjusted performance. But we use FF5FM to test the risk-adjusted performance. For robustness, we adopt two weighting schemes in performing the portfolio analysis: equally-weighted portfolios (EW), and value-weighted portfolios (VW).

\subsection{Portfolio Returns before Risk Adjustment}

Table 2 reports raw mean returns per month of portfolios formed on $B A 12$, LOT12, CS12, $\mathrm{C}^{\text {gibss }}$ and CO-cost, respectively. Panel A presents results of quintile portfolios in the pre-1963 period. For the $\mathrm{C}^{\text {gibss }}$-sorted EW (VW) portfolios, holding-period returns steadily increase from Low- to High- $\mathrm{C}^{\text {gibss }}$ portfolios and the $\mathrm{C}^{\text {gibbs }}$-based liquidity premium is significant at $0.867 \%(t=2.23)$ per month with EW and $0.680 \%(t=2.11)$ per month with VW. $C S 12$ and $\mathrm{C}^{g i b b s}$ perform similarly. For the BA12- and LOT12-sorted EW (VW) portfolios, liquidity premium is insignificant at $0.625 \%(t=1.86), 0.573 \%(t=1.65)$ per month with $\mathrm{EW}$, and $0.123 \%(t=0.54), 0.040 \%(t=0.16)$ per month with $\mathrm{VW}$, respectively. In addition, for the CO-cost-sorted VW portfolios, liquidity premium is significant at $0.677 \%(t=2.17)$ per month.

With NYSE/Amex/Arca ordinary common stocks over the post-1963 period, Panel B repots raw return per month of decile portfolios, which are classified using NYSE breakpoints. Among the five trading cost measures, the $\mathrm{C}^{\text {gibbs }}$ and CS12 show the stronger return predictability. In fact, the $\mathrm{C}^{\text {gibbs }}$-based $\mathrm{H}-\mathrm{L}$ premium is insignificant at $0.285 \%(t=1.24)$ per month for VW, $0.156 \%(t=0.70)$, is significant at $0.485 \%(t=1.96)$ per month for EW. For the other trading cost indicators, $\mathrm{H}-\mathrm{L}$ premium is insignificant per month for EW (VW).

Comparative analysis shows that BA12, LOT12, $\mathrm{C}^{\text {gibbs }}$ and CO-cost do not have the ability of expected return, and $\mathrm{C}^{\text {gibbs }}$ and $C S 12$ are better than $B A 12$, LOT12 and CO-cost.

${ }^{3}$ If a stock delists during the 12-month holding period, we set its post-delisting returns over the remaining holding-period months to zero. 
Table 2. Raw return per month of portfolios formed on BA12, LOT12,CS12, $\mathrm{C}^{\text {gibbs }}$ and Co-cost. (a) Raw return (\%) per month of quintile portfolios with NYSE ordinary common stocks over7/1927 to 6/1963; (b) Raw return (\%) per month of decile portfolios with NYSE/Amex/Arca ordinary common stocks over7/1963 to 6/2011.

(a)

\begin{tabular}{cccccccccccc}
\hline & \multicolumn{9}{c}{ EW } & \multicolumn{7}{c}{ VW } \\
\cline { 2 - 11 } & BA12 & LOT12 & CS12 & C $^{\text {gibls }}$ & Co-cost & BA12 & LOT12 & CS12 & C $^{\text {gibbs }}$ & Co-cost \\
\cline { 2 - 11 } & \multicolumn{2}{c}{$192707-196306$} & $192801-196312$ & \multicolumn{2}{c}{$192707-196306$} & $192801-196312$ \\
\hline Low & 0.968 & 0.970 & 0.983 & 0.877 & 0.874 & 0.920 & 0.943 & 0.946 & 0.898 & 0.918 \\
Q2 & 1.178 & 1.162 & 1.182 & 1.045 & 1.116 & 1.093 & 1.115 & 1.122 & 1.047 & 1.201 \\
Q3 & 1.297 & 1.255 & 1.238 & 1.241 & 1.157 & 1.259 & 1.114 & 1.033 & 1.206 & 1.285 \\
Q4 & 1.403 & 1.380 & 1.360 & 1.405 & 1.241 & 1.203 & 1.135 & 1.215 & 1.334 & 1.197 \\
High & 1.593 & 1.543 & 1.567 & 1.743 & 1.581 & 1.043 & 0.983 & 0.939 & 1.578 & 1.595 \\
& & & & & & & & & & \\
H-L & 0.625 & 0.573 & 0.584 & 0.867 & 0.708 & 0.123 & 0.040 & -0.007 & 0.680 & 0.677 \\
& $(1.86)$ & $(1.65)$ & $(1.68)$ & $(2.23)$ & $(1.79)$ & $(0.54)$ & $(0.16)$ & $(-0.03)$ & $(2.11)$ & $(2.17)$ \\
\hline
\end{tabular}

(b)

\begin{tabular}{ccccccccccc}
\hline & \multicolumn{9}{c}{ EW } & \multicolumn{7}{c}{ VW } \\
\cline { 2 - 10 } & BA12 & LOT12 & CS12 & C $^{\text {gibbs }}$ & Co-cost & BA12 & LOT12 & CS12 & C $^{\text {gibbs }}$ & Co-cost \\
\cline { 2 - 11 } & \multicolumn{2}{c}{$196307-201106$} & $196401-201012$ & \multicolumn{2}{c}{$196307-201106$} & $196401-201012$ \\
\hline Low & 0.987 & 0.928 & 0.949 & 1.029 & 1.076 & 0.913 & 0.876 & 0.884 & 0.879 & 0.928 \\
D2 & 1.055 & 0.976 & 1.055 & 1.096 & 1.088 & 0.969 & 0.841 & 0.870 & 0.924 & 1.043 \\
D3 & 1.066 & 0.934 & 1.036 & 1.100 & 1.212 & 0.945 & 0.963 & 0.910 & 0.926 & 1.085 \\
D4 & 1.087 & 0.991 & 1.009 & 1.117 & 1.031 & 0.952 & 0.980 & 0.876 & 0.882 & 1.012 \\
D5 & 1.117 & 1.116 & 1.056 & 1.102 & 1.175 & 0.996 & 1.045 & 0.873 & 0.921 & 1.044 \\
D6 & 1.166 & 1.122 & 1.079 & 1.139 & 1.081 & 1.098 & 0.907 & 0.924 & 0.883 & 1.109 \\
D7 & 1.159 & 1.142 & 1.101 & 1.107 & 1.110 & 1.031 & 1.045 & 0.916 & 1.008 & 1.205 \\
D8 & 1.175 & 0.980 & 1.185 & 1.243 & 1.256 & 1.006 & 1.056 & 0.948 & 1.123 & 1.118 \\
D9 & 1.159 & 1.030 & 1.128 & 1.300 & 1.499 & 1.339 & 0.799 & 0.919 & 1.182 & 1.308 \\
High & 1.289 & 1.058 & 1.108 & 1.514 & 1.553 & 1.094 & 1.084 & 0.891 & 1.164 & 1.377 \\
H-L & 0.302 & 0.129 & 0.159 & 0.485 & 0.476 & 0.180 & 0.208 & 0.007 & 0.285 & 0.449 \\
& $(1.33)$ & $(0.53)$ & $(0.71)$ & $(1.96)$ & $(1.54)$ & $(0.94)$ & $(0.76)$ & $(0.03)$ & $(1.24)$ & $(1.16)$ \\
\hline
\end{tabular}

\subsection{Portfolio Performance after Adjusting for the Three Fama-French Risks}

To adjust for risk, we rely on the FF3FM of Fama and French (1993) commonly used in the literature. Specifically, we estimate the following model:

$$
R_{i t}-R_{f t}=\alpha+\beta_{m}\left(R_{m t}-R_{f t}\right)+\beta_{s} S M B_{t}+\beta_{h} H M L_{t}+\varepsilon_{i t},
$$

where $R_{m t}-R_{f t}, S M B_{t}$, and $H M L_{t}$ are the month- $t$ values of the three FamaFrench factors: market, size, and book-to-market; $R_{i t}$ is the month- $t$ return of 
portfolio $i ; R_{f t}$ is the risk-free rate ${ }^{4}$ for month $t$.

Table 3 reports the FF3FM alphas of portfolios classified respectively by $B A 12$, LOT12, CS12, $\mathrm{C}^{\text {gibbs }}$ and CO-cost. Panel A reports the results of quintile portfolios with NYSE ordinary common stocks over 1926 to 1963. After adjusting for the FF3FM, CS12 and $\mathrm{C}^{\text {gibbs }}$ are completely lose them power to predict returns. The $\mathrm{C}^{\text {gibbs }}$-based premium after adjusting for the FF3FM is $0.343 \%(t=1.87)$, $0.256 \%(t=1.31)$ per month with EW and VW, respectively. In addition, the liquidity premium associated with $B A 12, L O T 12$ and $C O$-cost., is also insignificant regardless of EW or VW.

Panel B shows the results of decile portfolios with NYSE/AMEX/ARCA ordinary common stocks over 1963 to 2011, where decile portfolios are formed with NYSE breakpoints. The $\mathrm{C}^{\text {gibbs }}$-based premium after adjusting for the FF3FM is insignificant at $-0.102 \%(t=-0.56)$, and $-0.261 \%(t=-1.78)$ per month for EW and VW, respectively. In addition, based on the FF3FM, we don't observe a significantly positive liquidity premium associated with $B A 12, L O T 12, C S 12$ and CO-cost.

Overall, based on the FF3FM, there is no direct relationship between liquidity premium and transaction cost, the trading cost doesn't determine the stock return. The trading cost does not show significant return predictability. The result consistent with Constantinides (1986) that the impact of trading cost on asset return is second order.

\subsection{Portfolio Performance after Adjusting for the Five Fama-French Risks}

We run the FF5FM of Fama and French (2015) model:

$$
R_{i t}-R_{f t}=\alpha+\beta_{m}\left(R_{m t}-R_{f t}\right)+\beta_{s} S M B_{t}+\beta_{h} H M L_{t}+\beta_{r} R M W_{t}+\beta_{c} C M A_{t}+\varepsilon_{i t},
$$

where $R_{m t}-R_{f t}, S M B_{t}, H M L_{t}, R M W_{t}$ and $C M A_{t}$ are the month- $t$ values of the five Fama-French factors: market, size, book-to-market, profitability and investment; $R_{i t}$ is the month- $t$ return of portfolio $i ; R_{f t}$ is the risk-free rate $^{4}$ for month $t$.

Table 4 shows the results of decile portfolios with NYSE/Amex/Arca ordinary common stocks over 1963 to 2011, where decile portfolios are formed with NYSE breakpoints. In the case of EW portfolio return, the BA12-, LOT12-, CS12-, $\mathrm{C}^{\text {gibbs }}$ and $\mathrm{CO}$-cost -based premium after adjusting for the FF5FM is insignificant at $0.145 \%(t=0.79),-0.224 \%(t=-1.15),-0.324 \%(t=-2.15), 0.189 \%(t=1.09)$ and $0.172 \%(t=0.62)$ per month, respectively. In the case of VW portfolio return, the alpha of FF5FM is insignificant at $-0.066 \%(t=-0.43),-0.542 \%(t=$ $-2.48),-0.589 \%(t=-3.37),-0.068 \%(t=-0.44),-0.174 \%(t=-0.47)$ per month. The analysis results show that the trading cost does not show significant return predictability.

${ }^{4}$ Proxied by the one-month Treasury-Bill rate. 
Table 3. Portfolio performance after adjusting for the Fama-French three-factor model. (a) FF3FM alphas (\%) per month of quintile portfolios with NYSE ordinary common stocks over 7/1927-6/1963; (b) FF3FM alphas (\%) per month of decile portfolios with NYSE/Amex/Arca ordinary common stocks over 7/1963-6/2011.

(a)

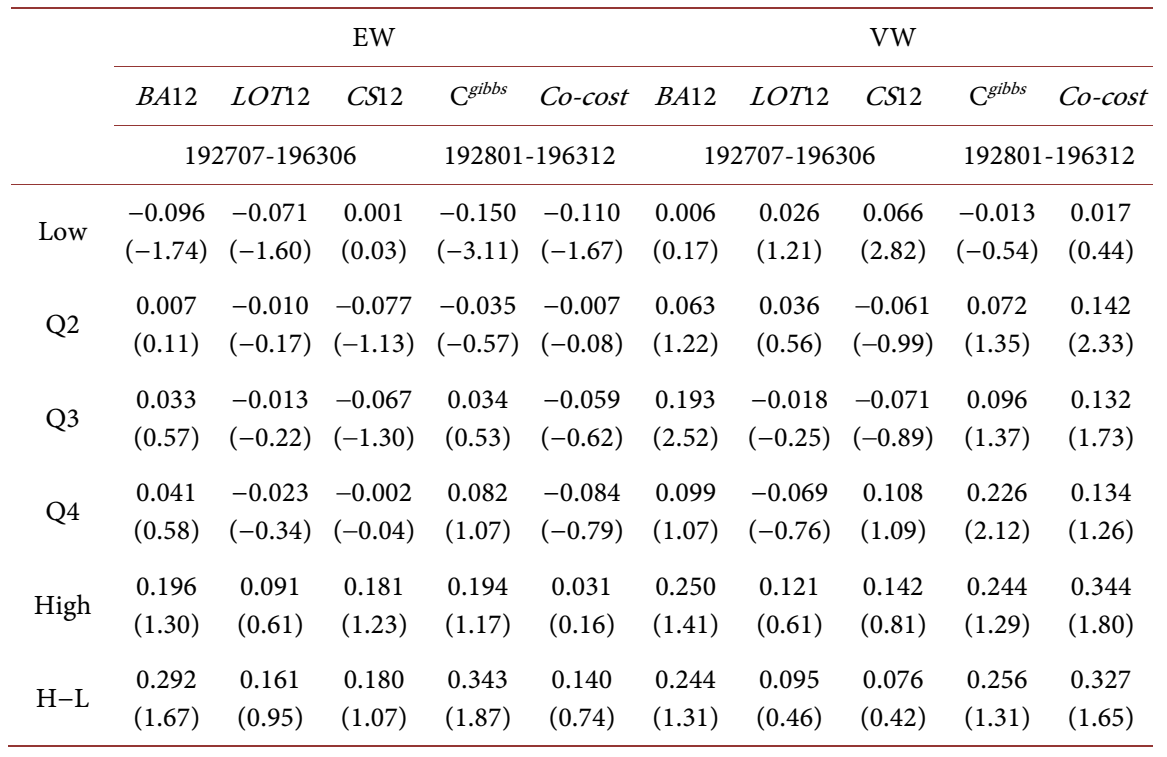

(b)

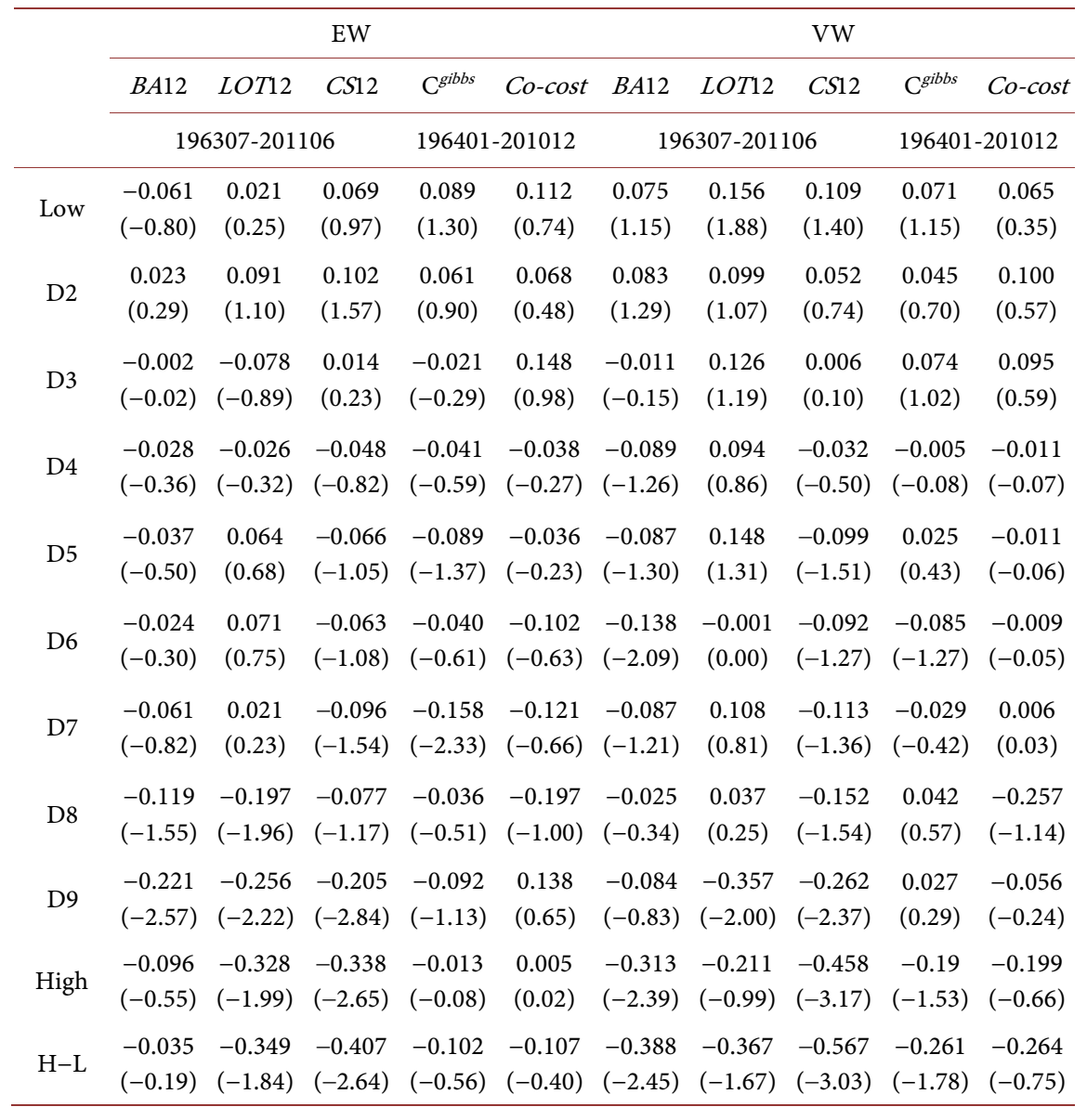


Table 4. Portfolio performance after adjusting for the Fama-French five-factor model.

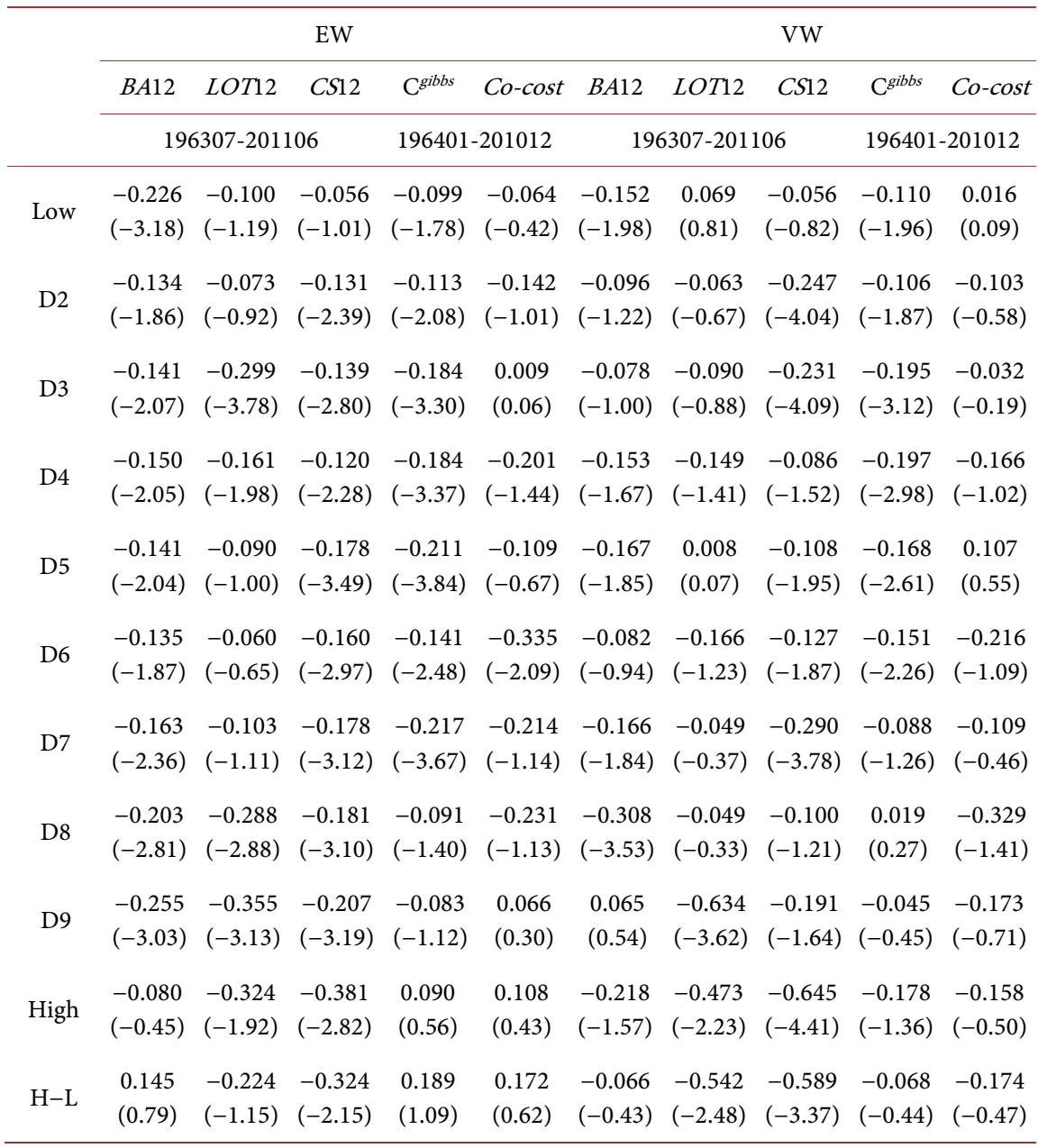

\section{Stock Level Cross-Sectional Regressions}

As an alternative way to examine the return predictability, we run the following cross-sectional regression:

$$
R_{i, t+m}-R_{f, t+m}=\gamma_{0}+\gamma_{1} \ln \left(M V_{i t}\right)+\gamma_{2} \ln \left(B / M_{i t}\right)+\gamma_{3} X_{i t}+\varepsilon_{i, t+m},
$$

where $R_{i, t+m}$ is stock is return in month $t+m(m=1,2, \cdots, 12), R_{f, t+m}$ is the one-month T-Bill rate for month $t+m, \ln \left(M V_{i, t}\right)$ is the natural logarithm of stock is market cap measured at the end of month $t, \ln \left(B / M_{i, t}\right)$ is the natural logarithm of stock is book-to-market ratio measured at the end of month $t$, and $X_{i t}$ is one of the four liquidity proxies measured at the end of month $t$. For each 12-month period from July $(t+1)$ to next June $(t+12)$, we run the regression each month on these regressors. To mitigate the influence of outliers on the regression results, we winsorize the top $0.5 \%$ observations and the bottom $0.5 \%$ observations of each independent variable. Also, following Amihud (2002), for each cross-sectional regression involving the regressor of RtoV 12 we deflate it by its cross-sectional mean. We calculate Litzenberger and Ramaswamy (1979) efficient estimates. That is, for each model parameter, it is estimated as the weighted 
average of the monthly estimates with weights being determined by the reciprocal of variances of the estimates.

Table 5 displays the cross-sectional regression results. The coefficient of BA12, LOT12, CS12, $\mathrm{C}^{\text {gibb }}$, CO-cost is insignificant at $-0.233(t=-0.72),-0.112$ $(t=-0.47),-0.147(t=-0.52), 0.146(t=1.03), 0.174(t=1.06)$ over the

Table 5. Cross-sectional regression analysis.

\begin{tabular}{|c|c|c|c|c|c|c|c|c|c|c|}
\hline & \multicolumn{3}{|c|}{ 192707-196306 } & \multicolumn{2}{|c|}{ 192801-196312 } & \multicolumn{3}{|c|}{ 196307-201106 } & \multicolumn{2}{|c|}{ 196401-201012 } \\
\hline & (1) & (2) & (3) & (4) & (5) & (1) & (2) & (3) & (4) & (5) \\
\hline alpha & $\begin{array}{l}1.268 \\
(2.42)\end{array}$ & $\begin{array}{l}1.429 \\
(3.08)\end{array}$ & $\begin{array}{l}1.086 \\
(2.39)\end{array}$ & $\begin{array}{l}1.382 \\
(2.93)\end{array}$ & $\begin{array}{l}1.398 \\
(2.97)\end{array}$ & $\begin{array}{l}1.232 \\
(3.05)\end{array}$ & $\begin{array}{l}1.624 \\
(4.94)\end{array}$ & $\begin{array}{l}1.442 \\
(3.38)\end{array}$ & $\begin{array}{l}1.572 \\
(5.06)\end{array}$ & $\begin{array}{l}1.543 \\
(3.74)\end{array}$ \\
\hline $\operatorname{Ln} M V$ & $\begin{array}{l}-0.020 \\
(-0.31)\end{array}$ & $\begin{array}{l}-0.061 \\
(-1.08)\end{array}$ & $\begin{array}{l}-0.021 \\
(-0.42)\end{array}$ & $\begin{array}{l}-0.061 \\
(-1.02)\end{array}$ & $\begin{array}{l}-0.047 \\
(-0.98)\end{array}$ & $\begin{array}{l}-0.010 \\
(-0.19)\end{array}$ & $\begin{array}{l}-0.060 \\
(-2.03)\end{array}$ & $\begin{array}{l}-0.038 \\
(-1.00)\end{array}$ & $\begin{array}{l}-0.064 \\
(-1.97)\end{array}$ & $\begin{array}{l}-0.041 \\
(-0.51)\end{array}$ \\
\hline $\operatorname{Ln} B M$ & $\begin{array}{l}0.213 \\
(1.62)\end{array}$ & $\begin{array}{l}0.267 \\
(1.94)\end{array}$ & $\begin{array}{l}0.180 \\
(1.80)\end{array}$ & $\begin{array}{l}0.236 \\
(1.68)\end{array}$ & $\begin{array}{l}0.098 \\
(1.05)\end{array}$ & $\begin{array}{l}0.140 \\
(1.79)\end{array}$ & $\begin{array}{l}0.114 \\
(1.64)\end{array}$ & $\begin{array}{l}0.141 \\
(1.84)\end{array}$ & $\begin{array}{l}0.155 \\
(2.61)\end{array}$ & $\begin{array}{l}0.056 \\
(0.46)\end{array}$ \\
\hline$B A 12$ & $\begin{array}{l}-0.233 \\
(-0.72)\end{array}$ & & & & & $\begin{array}{l}0.153 \\
(0.30)\end{array}$ & & & & \\
\hline LOT12 & & $\begin{array}{l}-0.112 \\
(-0.47)\end{array}$ & & & & & $\begin{array}{l}-0.802 \\
(-1.96)\end{array}$ & & & \\
\hline CS12 & & & $\begin{array}{c}0.37 \\
(1.94)\end{array}$ & & & & & $\begin{array}{c}-0.16 \\
(-0.49)\end{array}$ & & \\
\hline $\mathrm{C}^{g i b b s}$ & & & & $\begin{array}{l}0.146 \\
(1.03)\end{array}$ & & & & & $\begin{array}{l}0.182 \\
(0.60)\end{array}$ & \\
\hline Co-cost & & & & & $\begin{array}{l}0.174 \\
(1.06)\end{array}$ & & & & & $\begin{array}{l}0.066 \\
(0.28)\end{array}$ \\
\hline
\end{tabular}

Numbers in parentheses are $t$-statistics.

\begin{tabular}{|c|c|c|c|c|c|}
\hline & \multicolumn{3}{|c|}{ 192707-201106 } & \multicolumn{2}{|c|}{$192801-201012$} \\
\hline & (1) & (2) & (3) & (4) & (5) \\
\hline alpha & $\begin{array}{l}1.247 \\
(3.87)\end{array}$ & $\begin{array}{l}1.538 \\
(5.60)\end{array}$ & $\begin{array}{l}1.283 \\
(4.12)\end{array}$ & $\begin{array}{l}1.488 \\
(5.50)\end{array}$ & $\begin{array}{l}1.479 \\
(4.77)\end{array}$ \\
\hline $\operatorname{Ln} M V$ & $\begin{array}{l}-0.015 \\
(-0.35)\end{array}$ & $\begin{array}{l}-0.061 \\
(-2.02)\end{array}$ & $\begin{array}{l}-0.031 \\
(-1.00)\end{array}$ & $\begin{array}{l}-0.063 \\
(-1.96)\end{array}$ & $\begin{array}{l}-0.044 \\
(-0.87)\end{array}$ \\
\hline $\operatorname{Ln} B M$ & $\begin{array}{l}0.172 \\
(2.38)\end{array}$ & $\begin{array}{l}0.182 \\
(2.52)\end{array}$ & $\begin{array}{l}0.158 \\
(2.57)\end{array}$ & $\begin{array}{l}0.191 \\
(2.71)\end{array}$ & $\begin{array}{c}0.075 \\
(0.93)\end{array}$ \\
\hline$B A 12$ & $\begin{array}{l}-0.014 \\
(-0.04)\end{array}$ & & & & \\
\hline LOT12 & & $\begin{array}{l}-0.581 \\
(-1.98)\end{array}$ & & & \\
\hline CS12 & & & $\begin{array}{c}0.22 \\
(1.34)\end{array}$ & & \\
\hline $\mathrm{C}^{\text {gibbs }}$ & & & & $\begin{array}{l}0.166 \\
(0.93)\end{array}$ & \\
\hline Co-cost & & & & & $\begin{array}{c}0.113 \\
(0.75)\end{array}$ \\
\hline
\end{tabular}


pre-1963 period. The coefficient of $B A 12, C S 12, \mathrm{C}^{\text {gibb }}, C O$-cost is insignificant at $0.153(t=0.30),-0.675(t=-1.14), 0.182(t=0.60), 0.066(t=0.28)$ over the post-1963 period. The coefficient of LOT12 is significant at $-0.802(t=-1.96)$, but the economic significance is not significant. The coefficient of $B A 12, L O T 12$, $C S 12, \mathrm{C}^{\text {gibb }}, C O$-cost is insignificant at $-0.014(t=-0.04),-0.581(t=-1.98)$, $0.22(t=1.34), 0.166(t=0.93), 0.113(t=0.75)$ over the sample period. The coefficient of five trading cost is insignificant over the pre-1963 period, over the post-1963 period, and over the sample period. The result meaning that the trading cost fails to predict return. The cross-sectional regression results are consistent with the above portfolio analysis.

\section{Portfolio Performance after Adjusting for Liquidity Risk}

Recently, studies have shown that liquidity risk is important for asset pricing (see Pastor and Stambaugh (2003), Acharya and Pedersen (2005), Sadka (2006), and Liu (2006) for examples). To ascertain whether the trading cost has potential pricing implication, we use Pastor-Stambaugh (PS) model and the liquidity-augmented CAPM (LCAPM) of Liu (2006) to assess the performance of portfolios classified by BA12, LOT12, CS12, $\mathrm{C}^{\text {gibbs }}$ and CO-cost.

For the LCAPM, we run the following time-series regression:

$$
R_{i t}-R_{f t}=\alpha+\beta\left(R_{m t}-R_{f t}\right)+\beta_{l} L I Q_{t}+\varepsilon_{i t},
$$

where $L I Q_{t}$ is the month- $t$ value of Liu's (2006) mimicking liquidity risk factor.

For the Pastor-Stambaugh model, we run the following time-series regression:

$$
R_{i t}-R_{f t}=\alpha+\beta_{m}\left(R_{m t}-R_{f t}\right)+\beta_{s} S M B_{t}+\beta_{h} H M L_{t}+\beta_{P S} P S L_{t}+\varepsilon_{i t},
$$

where $P S L_{t}$ is the month- $t$ value of the PS liquidity factor. The PS liquidity factor values are only available from 1968 onwards.

Table 6, Panel A reports the LCAPM alphas per month of H-L portfolios with NYSE ordinary common stocks over July 1927 to June 1963. Panel B reports the LCAPM alphas per month of H-L portfolios with NYSE/Amex/Arca ordinary common stocks over July 1963 to June 2011. After adjusting for the LCAPM, the result show that $B A 12, L O T 12, C S 12, \mathrm{C}^{\text {gibbs }}$ and CO-cost fails to predict return.

Table 6, Panel C reports Pastor and Stambaugh (2003) model alphas per month of decile portfolios with NYSE/Amex/Arca ordinary common stocks over July 1968 to June 2011. After adjusting for the PS, the result show that $B A 12$, LOT12, CS12, $\mathrm{C}^{\text {gibbs }}$ and CO-cost fails to predict return.

\section{Robustness Tests}

For the portfolio analysis, the previous results over the pre-1963 period are based on quintile portfolios. Also, the above analysis excludes Nasdaq stocks. To check the robustness of the results, we use the sample containing NYSE/Amex/ Arca/Nasdaq ordinary common stocks and adopt decile portfolios over both preand post-1963 periods. Table 7 presents the results. Overall, these results are 
Table 6. Portfolio performance after adjusting for liquidity risk. (a) LCAPM alphas (\%) per month of H-L portfolios with NYSE ordinary common stocks over 7/1927-6/1963; (b) LCAPM alphas (\%) per month of H-L portfolios with NYSE/Amex/Arca ordinary common stocks over 7/1963-6/2011; (c) Pastor and Stambaugh (2003) model alphas (\%) per month of decile portfolios with NYSE/Amex/Arca ordinary common stocks over 7/1968$6 / 2011$.

(a)

\begin{tabular}{ccccccccccc}
\hline & \multicolumn{1}{c}{ EW } & \multicolumn{7}{c}{ VW } \\
\cline { 2 - 10 } & BA12 & LOT12 & CS12 & $\mathrm{C}^{\text {gibbs }}$ & Co-cost & BA12 & LOT12 & CS12 & $\mathrm{C}^{\text {gibbs }}$ & Co-cost \\
\cline { 2 - 10 } & \multicolumn{2}{c}{$192707-196306$} & $192801-196312$ & $192707-196306$ & $192801-196312$ \\
\hline \multirow{3}{*}{ H-L } & -0.096 & -0.192 & -0.212 & -0.053 & -0.283 & 0.111 & 0.027 & -0.042 & -0.032 & 0.017 \\
& $(-0.44)$ & $(-0.77)$ & $(-0.96)$ & $(-0.20)$ & $(-1.10)$ & $(0.55)$ & $(0.11)$ & $(-0.21)$ & $(-0.13)$ & $(0.07)$ \\
\hline
\end{tabular}

(b)

\begin{tabular}{ccccccccccc}
\hline & \multicolumn{1}{c}{ EW } & \multicolumn{1}{c}{ VW } \\
\cline { 2 - 10 } & BA12 & LOT12 & CS12 & $\mathrm{C}^{\text {gibbs }}$ & Co-cost & BA12 & LOT12 & CS12 & $\mathrm{C}^{\text {gibbs }}$ & Co-cost \\
\cline { 2 - 9 } & $196307-201106$ & $196401-201112$ & $196307-201106$ & $196401-201012$ \\
\hline \multirow{3}{*}{ H-L } & -0.230 & -0.444 & -0.348 & -0.020 & -0.108 & -0.128 & -0.237 & -0.152 & -0.115 & -0.072 \\
& $(-1.01)$ & $(-1.84)$ & $(-1.60)$ & $(-0.08)$ & $(-0.34)$ & $(-0.65)$ & $(-0.85)$ & $(-0.60)$ & $(-0.50)$ & $(-0.18)$ \\
\hline
\end{tabular}

(c)

\begin{tabular}{|c|c|c|c|c|c|c|c|c|c|c|}
\hline & \multicolumn{5}{|c|}{ EW } & \multicolumn{5}{|c|}{ VW } \\
\hline & $B A 12$ & LOT12 & $C S 12$ & $\mathrm{C}^{g i b b s}$ & Co-cost & $B A 12$ & LOT12 & $C S 12$ & $\mathrm{C}^{g i b b s}$ & Co-cost \\
\hline & \multicolumn{3}{|c|}{ 196807-201106 } & \multicolumn{2}{|c|}{$196801-201012$} & \multicolumn{3}{|c|}{$196807-201106$} & 196801 & -201012 \\
\hline $\mathrm{H}-\mathrm{L}$ & $\begin{array}{l}-0.065 \\
(-0.33)\end{array}$ & $\begin{array}{l}-0.365 \\
(-1.73)\end{array}$ & $\begin{array}{l}-0.412 \\
(-2.67)\end{array}$ & $\begin{array}{l}-0.092 \\
(-0.46)\end{array}$ & $\begin{array}{l}-0.105 \\
(-0.35)\end{array}$ & $\begin{array}{l}-0.248 \\
(-1.49)\end{array}$ & $\begin{array}{l}-0.406 \\
(-1.72)\end{array}$ & $\begin{array}{l}-0.573 \\
(-3.06)\end{array}$ & $\begin{array}{l}-0.433 \\
(-2.46)\end{array}$ & $\begin{array}{l}-0.105 \\
(-0.35)\end{array}$ \\
\hline
\end{tabular}

Table 7. Performance of portfolios with NYSE/Amex/Arca/Nasdaq ordinary common stocks. (a) Results over 1927-1963 (NYSE stocks); (b) Results over 1963-2011 (NYSE/ Amex/Arca/Nasdaq stocks with decile portfolios formed based on NYSE breakpoints); (c) Results over 1927-2011 (NYSE/Amex/Arca/Nasdaq stocks with decile portfolios formed based on NYSE breakpoints).

(a)

\begin{tabular}{|c|c|c|c|c|c|c|c|c|c|c|}
\hline & \multicolumn{5}{|c|}{ EW } & \multicolumn{5}{|c|}{ VW } \\
\hline & $B A 12$ & LOT12 & $C S 12$ & $\mathrm{C}^{g i b b s}$ & Co-cost & $B A 12$ & LOT12 & $C S 12$ & $\mathrm{C}^{g i b b s}$ & Co-cost \\
\hline & \multicolumn{3}{|c|}{$192707-196306$} & \multicolumn{2}{|c|}{$192801-196312$} & \multicolumn{3}{|c|}{$192707-196306$} & \multicolumn{2}{|c|}{ 192801-196312 } \\
\hline $\mathrm{H}-\mathrm{L}$ & $\begin{array}{l}0.813 \\
(1.96)\end{array}$ & $\begin{array}{l}0.676 \\
(1.55)\end{array}$ & $\begin{array}{l}0.777 \\
(1.80)\end{array}$ & $\begin{array}{l}1.105 \\
(2.18)\end{array}$ & $\begin{array}{l}1.009 \\
(1.98)\end{array}$ & $\begin{array}{l}0.025 \\
(0.09)\end{array}$ & $\begin{array}{l}0.007 \\
(0.03)\end{array}$ & $\begin{array}{l}0.027 \\
(0.10)\end{array}$ & $\begin{array}{l}0.889 \\
(1.94)\end{array}$ & $\begin{array}{l}0.875 \\
(2.03)\end{array}$ \\
\hline$\alpha_{F F 3 F M}$ & $\begin{array}{l}0.443 \\
(1.79)\end{array}$ & $\begin{array}{l}0.203 \\
(0.80)\end{array}$ & $\begin{array}{l}0.273 \\
(1.13)\end{array}$ & $\begin{array}{l}0.436 \\
(1.61)\end{array}$ & $\begin{array}{l}0.317 \\
(1.14)\end{array}$ & $\begin{array}{l}0.228 \\
(0.91)\end{array}$ & $\begin{array}{l}0.048 \\
(0.18)\end{array}$ & $\begin{array}{l}0.120 \\
(0.50)\end{array}$ & $\begin{array}{l}0.257 \\
(0.99)\end{array}$ & $\begin{array}{l}0.467 \\
(1.46)\end{array}$ \\
\hline$\alpha_{L C A P M}$ & $\begin{array}{l}0.010 \\
(0.03)\end{array}$ & $\begin{array}{l}-0.181 \\
(-0.54)\end{array}$ & $\begin{array}{l}-0.147 \\
(-0.47)\end{array}$ & $\begin{array}{l}-0.065 \\
(-0.18)\end{array}$ & $\begin{array}{l}-0.157 \\
(-0.43)\end{array}$ & $\begin{array}{l}0.145 \\
(0.55)\end{array}$ & $\begin{array}{l}0.014 \\
(0.05)\end{array}$ & $\begin{array}{l}0.035 \\
(0.13)\end{array}$ & $\begin{array}{l}-0.142 \\
(-0.42)\end{array}$ & $\begin{array}{l}0.150 \\
(0.41)\end{array}$ \\
\hline
\end{tabular}


(b)

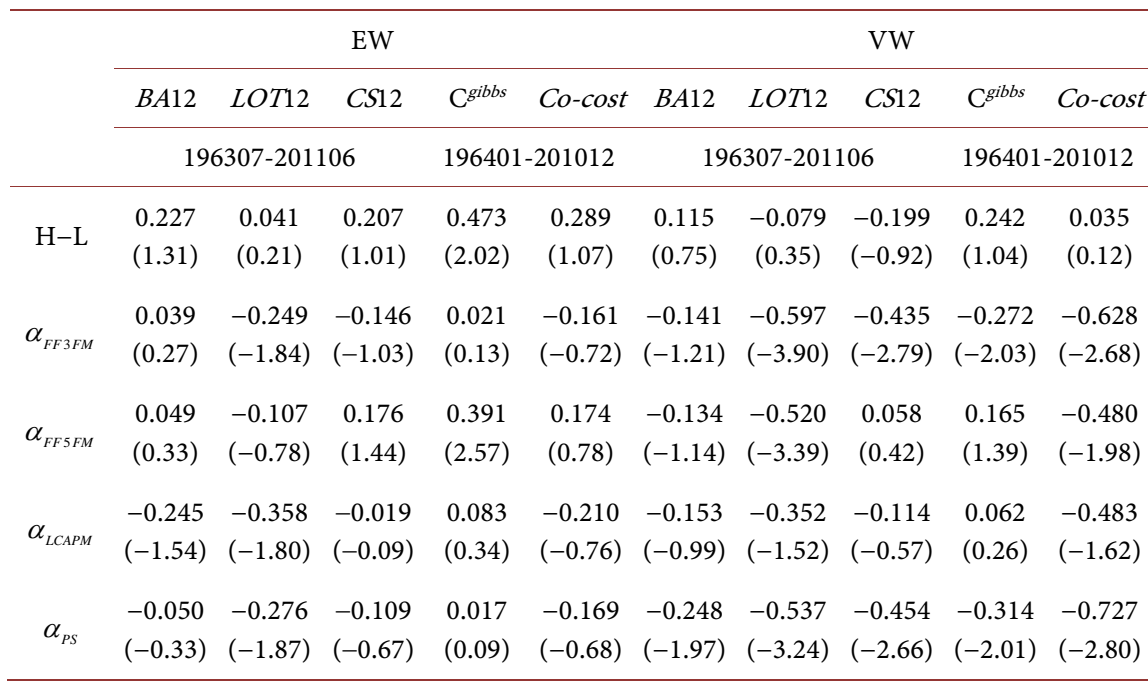

(c)

\begin{tabular}{|c|c|c|c|c|c|c|c|c|c|c|}
\hline & \multicolumn{5}{|c|}{ EW } & \multicolumn{5}{|c|}{ VW } \\
\hline & $B A 12$ & LOT12 & $C S 12$ & $\mathrm{C}^{g i b b s}$ & Co-cost & $B A 12$ & LOT12 & $C S 12$ & $\mathrm{C}^{g i b b s}$ & Co-cost \\
\hline & \multicolumn{3}{|c|}{$192707-201106$} & \multicolumn{2}{|c|}{$192801-201012$} & \multicolumn{3}{|c|}{$192707-201106$} & \multicolumn{2}{|c|}{$192801-201012$} \\
\hline $\mathrm{H}-\mathrm{L}$ & $\begin{array}{l}0.481 \\
(2.35)\end{array}$ & $\begin{array}{l}0.320 \\
(1.45)\end{array}$ & $\begin{array}{l}0.333 \\
(1.55)\end{array}$ & $\begin{array}{l}0.744 \\
(2.91)\end{array}$ & $\begin{array}{l}0.594 \\
(2.21)\end{array}$ & $\begin{array}{l}0.076 \\
(0.50)\end{array}$ & $\begin{array}{l}0.041 \\
(0.22)\end{array}$ & $\begin{array}{l}-0.132 \\
(-0.79)\end{array}$ & $\begin{array}{l}0.519 \\
(2.19)\end{array}$ & $\begin{array}{l}0.394 \\
(1.57)\end{array}$ \\
\hline$\alpha_{F F 3 F M}$ & $\begin{array}{l}0.057 \\
(0.40)\end{array}$ & $\begin{array}{l}-0.203 \\
(-1.41)\end{array}$ & $\begin{array}{l}-0.174 \\
(-1.18)\end{array}$ & $\begin{array}{l}0.043 \\
(0.27)\end{array}$ & $\begin{array}{l}-0.116 \\
(-0.64)\end{array}$ & $\begin{array}{l}0.066 \\
(0.50)\end{array}$ & $\begin{array}{l}-0.203 \\
(-1.41)\end{array}$ & $\begin{array}{l}-0.208 \\
(-1.38)\end{array}$ & $\begin{array}{l}-0.177 \\
(-1.21)\end{array}$ & $\begin{array}{l}-0.148 \\
(-0.76)\end{array}$ \\
\hline$\alpha_{L C A P M}$ & $\begin{array}{l}-0.272 \\
(-1.69)\end{array}$ & $\begin{array}{l}-0.462 \\
(-2.46)\end{array}$ & $\begin{array}{l}-0.392 \\
(-2.10)\end{array}$ & $\begin{array}{l}-0.242 \\
(-1.15)\end{array}$ & $\begin{array}{l}-0.389 \\
(-1.72)\end{array}$ & $\begin{array}{l}0.045 \\
(0.31)\end{array}$ & $\begin{array}{l}-0.158 \\
(-0.85)\end{array}$ & $\begin{array}{l}-0.132 \\
(-0.77)\end{array}$ & $\begin{array}{l}-0.305 \\
(-1.49)\end{array}$ & $\begin{array}{l}-0.273 \\
(-1.17)\end{array}$ \\
\hline
\end{tabular}

consistent with our previous findings. Our previous findings are robust.

\section{Conclusion}

In this paper, we conduct examination on the classic trading cost BA12, LOT, CS12 and $C^{\text {gibbs }}$. We focus on whether the trading cost is the decisive factor of asset returns, whether pricing ability of transaction cost is the first order or the second order. Our tests mainly rely on the Fama-French three-factor model (FF3FM) as the benchmark. Our empirical results show that the transaction cost has little power to predict return. The empirically testable implication is that the transaction cost is second-order effects on return. The results indicate that the transaction cost may be safely ignored in the real asset pricing theory. The conclusion provides rich empirical evidence for the theory of Constantinides (1986). Our conclusion also shows that CS12 and $C^{\text {gibbs }}$ can not only describe the transaction cost better, but also they are better than LOT12 in the expected stock return. We have only studied the stock market of the United States, and we can also study the situation of other developed capital markets and emerging markets in the future. 


\section{Conflicts of Interest}

The authors declare no conflicts of interest regarding the publication of this paper.

\section{References}

Acharya, V., \& Pedersen, L. H. (2005). Asset Pricing with Liquidity Risk. Journal of Financial Economics, 77, 375-410. https://doi.org/10.1016/j.jfineco.2004.06.007

Amihud, Y. (2002). Illiquidity and Stock Returns: Cross-Section and Time-Series Effects. Journal of Financial Markets, 5, 31-56. https://doi.org/10.1016/S1386-4181(01)00024-6

Amihud, Y., \& Mendelson, H. (1986). Asset Pricing and the Bid-Ask Spread. Journal of Financial Economics, 17, 223-249. https://doi.org/10.1016/0304-405X(86)90065-6

Anthony, W. L., \& Tan, S. (2011). Explaining the Magnitude of Liquidity Premia: The Roles of Return Predictability, Wealth Shocks, and State-Dependent Transaction Costs. The Journal of Finance, 66, 1329-1368. https://doi.org/10.1111/j.1540-6261.2011.01662.x

Brennan, M. J., \& Subrahmanyam, A. (1996). Market Microstructure and Asset Pricing: On the Compensation for Illiquidity in Stock Returns. Journal of Financial Economics, 41, 441-464. https://doi.org/10.1016/0304-405X(95)00870-K

Brennan, M. J., Chordia, T., \& Subrahmanyam, A. (1998). Alternative Factor Specifications, Security Characteristics, and the Cross-Section of Expected Stock Returns. Journal of Financial Economics, 49, 345-373.

Brennan, M. J., Chordia, T., Subrahmanyam, A., \& Tong, Q. (2012). Sell-Order Liquidity and the Cross-Section of Expected Stock Returns. Journal of Financial Economics, 105, 523-541. https://doi.org/10.1016/j.jfineco.2012.04.006

Constantinides, G. (1986). Capital Market Equilibrium with Transaction Costs. Journal of Political Economy, 94, 842-862. https://doi.org/10.1086/261410

Corwin, S. A., \& Schultz, P. (2012). A Simple Way to Estimate Bid-Ask Spreads from Daily High and Low Prices. The Journal of Finance, 67, 719-760.

https://doi.org/10.1111/j.1540-6261.2012.01729.x

Davis, J. L., Fama, E. F., \& French, K. R. (2000). Characteristics, Covariances, and Average Returns: 1929 to 1997. The Journal of Finance, 55, 389-406. https://doi.org/10.1111/0022-1082.00209

Demsetz, H. (1968). The Cost of Transaction. The Quarterly Journal of Economics, 82, 33-53. https://doi.org/10.2307/1882244

Fama, E. F., \& French, K. R. (1993). Common Risk Factors in the Returns on Stocks and Bonds. Journal of Financial Economics, 33, 3-56. https://doi.org/10.1016/0304-405X(93)90023-5

Fama, E. F., \& French, K. R. (2015). A Five-Factor Asset Pricing Model. Journal of Financial Economics, 116, 1-22. https://doi.org/10.1016/j.jfineco.2014.10.010

Gallop, R. J. (2007). NLP for MLE: Non-Linear Programming for Maximum Likelihood Estimation. Statistics and Data Analysis, NESUG.

Goyenko, R. Y., Holden, C. W., \& Trzcinka, C. A. (2009). Do Liquidity Measures Measure Liquidity? Journal of Financial Economics, 92, 153-181.

https://doi.org/10.1016/j.jfineco.2008.06.002

Hasbrouck, J. (2003). Intraday Price Formation in US Equity Index Markets. The Journal of Finance, 58, 2375-2399. https://doi.org/10.1046/j.1540-6261.2003.00609.x 
Hasbrouck, J. (2009). Trading Costs and Returns for U.S. Equities: Estimating Effective Costs from Daily Data. Journal of Finance, 64, 1445-1477. https://doi.org/10.1111/j.1540-6261.2009.01469.x

Lesmond, D. A., Ogden, J. P., \& Trzcinka, C. A. (1999). A New Estimate of Transaction Costs. Review of Financial Studies, 12, 1113-1141. https://doi.org/10.1093/rfs/12.5.1113

Litzenberger, R. H., \& Ramaswamy, K. (1979). The Effects of Personal Taxes and Dividends on Capital Asset Prices: Theory and Empirical Evidence. Journal of Financial Economics, 7, 163-195. https://doi.org/10.1016/0304-405X(79)90012-6

Liu, W. (2006). A Liquidity-Augmented Capital Asset Pricing Model. Journal of Financial Economics, 82, 631-671. https://doi.org/10.1016/j.jfineco.2005.10.001

Liu, W., \& Strong, N. C. (2008). Biases in Decomposing Holding Period Portfolio Returns. Review of Financial Studies, 21, 2243-2274. https://doi.org/10.1093/rfs/hhl034

Pastor, L., \& Stambaugh, R. F. (2003). Liquidity Risk and Expected Stock Returns. Journal of Political Economy, 111, 642-685. https://doi.org/10.1086/374184

Roll, R. (1984). A Simple Implicit Measure of the Effective Bid-Ask Spread in an Efficient Market. The Journal of Finance, 39, 1127-1139. https://doi.org/10.1111/j.1540-6261.1984.tb03897.x

Sadka, R. (2006). Momentum and Post-Earnings-Announcement Drift Anomalies: The Role of Liquidity Risk. Journal of Financial Economics, 80, 309-349.

https://doi.org/10.1016/j.jfineco.2005.04.005

Shumway, T. (1997). The Delisting Bias in CRSP Data. The Journal of Finance, 52, 327-340. https://doi.org/10.1111/j.1540-6261.1997.tb03818.x

Vayanos, D. (1998). Transaction Costs and Asset Prices: A Dynamic Equilibrium Model. Review of Financial Studies, 11, 1-58. https://doi.org/10.1093/rfs/11.1.1

Vayanos, D., \& Vila, J.-L. (1999). Equilibrium Interest Rate and Liquidity Premium with Transaction Costs. Economic Theory, 13, 509-539.

https://doi.org/10.1007/s001990050268 